\title{
Outbreak of Tomato yellow leaf curl virus(Family Geminiviridae) in Georgia
}

S. S. Pappu, Department of Entomology, and H. R. Pappu and D. B. Langston, Jr., Department of Plant Pathology, University of Georgia, Coastal Plain Experiment Station, Tifton, GA 31793; J. T. Flanders,University of Georgia Cooperative Extension Service, Cairo, GA 31728; D. G. Riley, Department of Entomology, and J. C. Diaz-Perez, Department of Horticulture, University of Georgia, Coastal Plain Experiment Station, Tifton, GA 31793

Posted 1 June 2000. Plant Health Progress doi:10.1094/PHP-2000-0601-02-HN.

Tomato yellow leaf curl virus (TYLCV) of the family Geminiviridae is a serious production constraint to tomato (3). In the southeastern United States the virus has been largely confined to Florida. The disease appeared in the southern most Georgia county (Decatur) in 1998, at an incidence rate of less than 1\% (2). During the fall of 1999, tomato plants showing symptoms indicative of TYLCV were observed in commercial fields in Grady, Colquitt, and Lowndes counties and the experimental plots of the Coastal Plain Experiment Station in two locations in Tift County, GA. The 12-acre commercial field in Grady County had a disease incidence of 15\%. In Tift County, in both experimental plots (approximately 5 miles apart), TYLCV incidence ranged from 15 to 20\%. Bemisia argentifolii populations in southern Georgia, based on the observed high incidence of silverleaf symptoms in squash and the intensity of adult migrations during August and September, were the highest in more than 5 years. TYLCV infection was verified by polymerase chain reaction (PCR) amplification with degenerate primers (5(prime)-GCC CAC ATY GTC TTY CCN GT-3(prime) and 5(prime)-GGC TTY CTR TAC ATR GG-3(prime)) specific to the DNA A component (4). A simplified and faster DNA extraction procedure was used to obtain PCR-ready templates. Leaf tissue was homogenized in $300 \mu \mathrm{l}$ of extraction buffer (1), followed by one phenol and one chloroform/isoamyl alcohol (24:1) extraction. The supernatant was purified using a QiaPrep MiniPrep purification kit (Qiagen, Valencia, CA) and was used in PCR amplification. The procedure yielded highly consistent PCR-quality template. The resulting approximately 1.3-kb PCR product was cloned in pGEM-T vector (Promega Corp., Madison, WI) and completely sequenced. Sequence comparisons indicated 98\% identity with known TYLCV isolates from Spain (GenBank Accession no. AJ223505), the Dominican Republic (GenBank Accession no. AFo24715), and Israel (GenBank Accession no. X15656). Using PCR followed by restriction digestion analysis, three symptomatic plants from one field each in Colquitt and Lowndes counties were TYLCV positive. The higher incidence of TYLCV in the Georgia counties of Tift and Grady and its concurrent occurrence in Colquitt and Lowndes counties indicates its rapid spread in the southeastern United States.

\section{References}

1. I. B. Dry et al. J. Gen. Virol. 74:147, 1993.

2. M. T. Momol et al. Plant Dis. 83:487, 1999.

3. J. E. Polston et al. Plant Dis. 83:984, 1999.

4. M. R. Rojas et al. Plant Dis. 77:340, 1993. 